\title{
汗腺キ發見シ得タル動物ノ種類二就テ
}

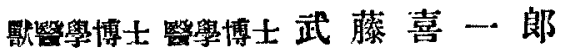 (陸軍㽬翳掌校)}

夏季二於テ疾走セル犬ガ廣クロヨ開キ長ク舌ヨ垂レ喘々トシラ 流涎スル所以，モノ八皮膚面ノ發汗二代ッラ行ハル、舌面ノソレ ナルコト 入朁二古キ時代二於ラ說明セラレタリ本邦及ビ支那二於 ラ汗牛ナル周知〉語い之レアレドモ未代賞テ汗馬ナル交字习熟語 トシテンレ程マデニ多ク用キズンレガ篇二牛ハ馬ョリモ多ク發汗 スル動物トシテ誤認セラレタル事アリ又人ガ發汗スルノ故ヨ以ラ 凡ラ，哺乳動物モ亦然ルベシト推測シ甚ダシキ二至ッテハ男子， 發汗二特殊ノ息氯アリテ婦人ノンレト全然相違スルントヨ根譃卜 シ汗液人臭氣 $フ$ 以ラ動物ノ雌雄

大正 5 年及ビ 6 年， 2 回二亘り余 八東京帝國大學醫科大學紀要 二於テ汗分泌种經二關スル論文ヨ公表シ次デ大正 7 年 9 月二至り ソレ等 $゙$ 綜合シ陸軍獸醫㯖報二揭載シタリ本論主張ノ要點ハ即チ 次ノ如シ

汗分泌神經八從桃汎ク世二知ラレタル交感神經ノミニ非ズシテ 交感神經及ビ副交感神經， 2 種類ナリ而シテ此等ノ兩神經ガ汗腺 二分布スル狀態ハ恰モ雨神經ガ共二分泌神經トシラ唾液腺二分布 スルガ如シ左りナガラ兩神經ガ汗分泌ヨ主宰スル作用八動物ノ種 類二恢り區々ニシテ人㸱及ビ猫ニアリテハ副交威神經が主働习演

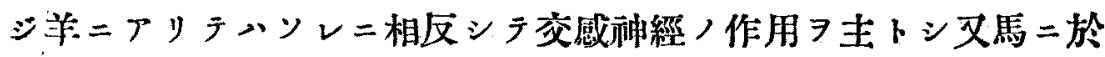
テハ雨神經トモ著シキ發讦作用 $习$ 呈ス倘示馬二於ヶル交感神經性

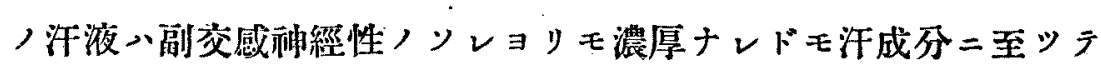

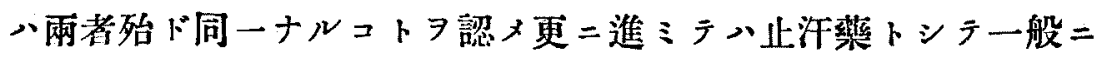
知レ渡りタルすをろぴんノ大量ヨ馬二用ユレバ腦 ヨ興奮シ次デ顯 
著ナル發汗ヨ生ズルモ此大發汗》最モ有力ナル發汗䒚トシラ世二 承認セラレタルぴろかるぴんラ以テ完全二制止スルコトヨ得べキ 奇怪ナル現象ヨ生ゼシガ之レ決シテ不可思議ニアラズ既ニ汗分泌 融經ガ 2 種類ナルコトフ發見シタル以上八此現象 $\ni$ 解釋スルコト 玉甚ダ容易ナリ即チ馬ノおころぴん發汗ハ腦興奮ノ篇二現ハレタ ルモノナレバ腦二向テ鎮静作用习有スルびろかるびんが制止作用 ヨ呈スルハ當然ナルベシ勿論其際ニぴろかるびんが副交威神經 末梢习刺韩シラ烱起スべき發汗作用ハあころびんノ此神經末梢二 於ケル麻痻作用ノ篇二制止七ラルベシ且ッ馬二於ケルすをろびん

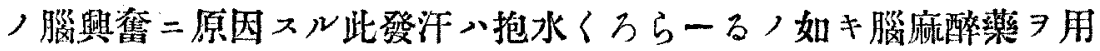
エルニ依ラ完全二制止スルントヨ得ル事實モ亦本論，立脚點 層確實二七り

以上ノ余ノ汗分泌神經二重分布論二對シ其後, 研究二於賛成 セラレタルハ Neumann (Wiener klin. Wochenschr. Jg. 29. S. 972. J. 1916) Billigheimer (Münch. med. Wochenschr. Jg. 68. S. 325. J. 1921）八兩氏ニシラ反對セラレタルハ早川醫學士（南滿醫學 堂硁誌第 11 卷第 7 號大正 12 年 5 月）ナリ同學士ノ說二據レバ Langley ガ解剖學上八見地ヨリ精密二䂨究シラ發見シタリシ紊威神 經コソ唯一ノ汗分泌神經ナルガ此交威神經が何故 =カ人及ビ猫 = 於テ八汗腺ノミ二限りテ本來ノ交感神經ノ如キ反應习呈セズシテ 却テ全ク副艾感神經ノ如ク反應スル所以ノモノ八何カ／原因二依 リテ神經ノ作用二變化习桃セシモノナルベシト推定シ又交感神經 二對スル特殊ノ刺戟劑タルおごれなりんガ人及ビ猫二於テ發汗作

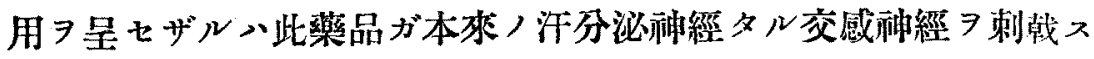

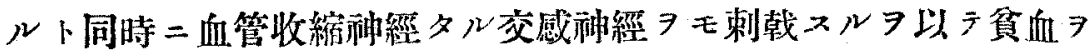
桃シンレガ篇二發汗ラ妨害スルモノトシラ穞當ナル解释习得べシ ト走張セラレタり 
此反對論二對シテハ次二答へ置カントス

あごれなりんノ貧血作用ガあごれなりんノ發汗作用习蓋つト云 ヘル推定論入理論トシテハ旮分ナル價值ヨ有スレドモ如何セン馬 特二羊ニおごれなりんヨ皮下注入スレバ注入局所二著明ナル重血

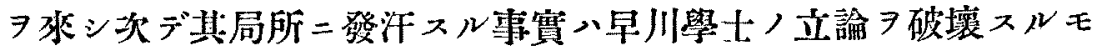
ノニ八非ルカ人心多クノ場合二於テ皮膚面二發赤シ次デ發汗スレ ドモ時トシテハンレノ反對二警宱二際シ顔面荅日トナリ次方前額 及ビ腋下ヨリ著シク發汗スルガ如キ周知ノ事暂モ同氏，說卜ハ全 然相容レザルモノナリ又人牛及ビ猫二於テびるかるびんヨ以ラ發 汗シおころぴんヨ以テ止汗スル現象 フ解釋センガ篇二汗分泌神經 タル交感神經ガ副交感神經ノ如ク變性シタリト云ハンョリモ寧口 此汗分泌神經 副艾威神經ナリト認ムルヨ却テ穞當ナリトハセザ

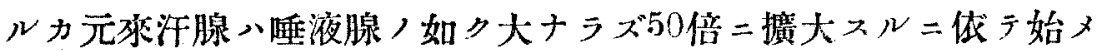

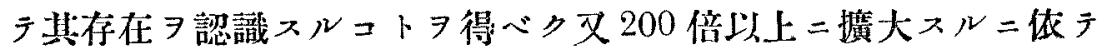
始メラ血管及ビ神縚ガンレニ分布スル構造 バ㕠髓ノ神經根部ノヨリ神經瀻維

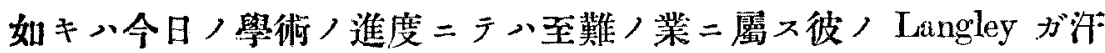

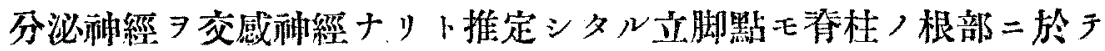

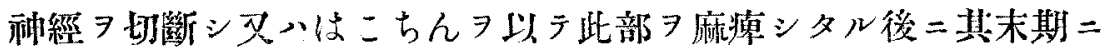
於ケル反應习調查シタル成績二外ナラザルコトア考フレバ余ガ藥 物ノ特殊反應 $\ni$ 根據トジ种經分布 $\ni$ 芒證シタルコトア Langley ノ成績二比シテ不完全ナりト云フハ抑モ酷ニシテ又極メテ非ナリ 卜信ズ余，汗分泌种經二重分布二對スル区論二答フ可キコトハ以 上ニシテ鞇キタレバコレヨリ本諭ノ目的トスル方向二移行セント ス

第 1 回ノ汗分泌神經諭 7 世二公表シラ以來既 $=7$ 筒年 7 經過

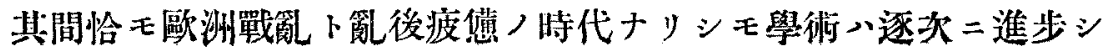


テ棑リ余ノ學友い人二於ケル微量，發汗即チ无斯形二於テ發散

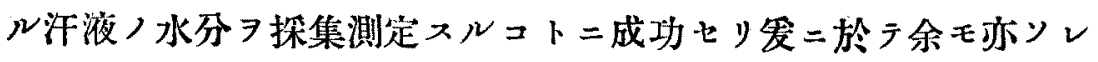
二模敒シ汻腺 $ヨ$ 有スル各種ノ動物二就テ假命其發汗微量ナルニセ

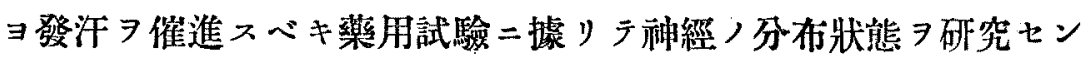
トスル希望习生シ其學友ノ非常ナル好意,下二究究裝置 9 殆ド完 成セりソレガ篇二余ガ今日マデ繼續セシ組織學的斫究ノ成績 7 纆 メ每䨖二報告セント欲ス蓋シ一般ノ動物二於ケル此汗腺組織ノ研 究、今後佾示多年 7 要シ勿論余自身ノミニテ完了セラルべキ性質 ノと ニ非ルヨ以テ此機會ニ於テ一段トナス心定二止ムヨ得ザレ ベ+y

從來人馬牛羊及ビ猫 發汗動物トシラ世二知ラレ又其汗腺ノ構 造二就キテモ砳究セラレダリシ余ニ至リテメンレ等ノ研究ヨ詳細 二反復シタル外二劣ホ猿犬山羊白鼠家鼠南京鼠鹿野猪豚，9種， 動物二就テモ汗腺ヨ發見セり然ル二海猽家鬼熊二就テハ發見スル コトヨ得ザリキ而シテ汗腺ヨ認メ得タル以上 14 種ノ動物二於ケ

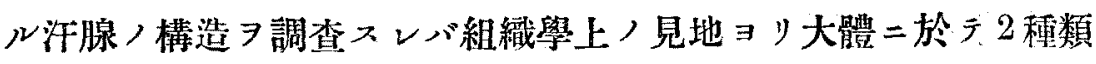
二區別スルコトヨ得ベシ其一八囊狀汗腺ニシテ他ノ一メ絲球狀汗 腺ナリ勿論其中間二位スト認ムルモノアレドモ余》便宜上ンレ等 ７單二 2 種類トナシタリ又一動物〉皮膚ノ各部 取ラ研究スルナラバ部位二ヨリ多少構造 9 異ニスル汗腺 $コ$ 有スル モノナシトモ限ラレザルベキモ概ジ云へバ絲球狀汗腺ヨ有スル モノ八多汗動物ナルガンレニ相反シテ囊狀汗腺 $フ$ 有スルモ，少汗 動物ナリ

（1）所謂絲球狀汗腺 發見シタル動物ハ人馬猫羊猪猿鹿豚南京 鼠白鼠家鼠, 11種

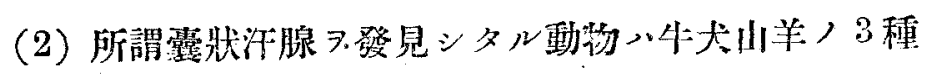

（3）汗腺ヨ發見シ得ザリシ動汤ハ游猽（各部二於テ）家要（各 
部二於テ）熊（前肢ノ管部及ビ肩胛部）ノ3 種

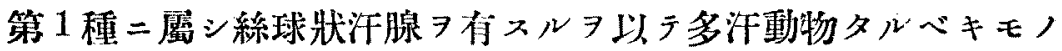
ニアリテモ今日マデ二頃際二藥用試驗 羊ノ 4 種二過ギズシラ殘稌ノ 7 種二就キテハ斫究未了ナリ

第 2 種二屬スル囊狀汗腺ノ動物中二テ牛ハ樂用二㑈りテ著明二 發汗スレドモ犬ト山羊トニ於ケル從前ノ藥用試驗ハ陰性ナリシ俱 シ其發汗試驗 ナレバ假り二發汗スルトモ其量少クシテ死斯形二於テ發散スレバ 發汗トシテ認識スルコトヨ得ザルタメニ陰性トナルモノナルぶシ 第 3 種ノ汗腺 7 發見七ザリシ動物卜 以余ノ研究二於テ發見スル コトヨ得ザリシマデニシラ份ホー磨詳細二砄究スレバ身體ノ何レ カノ部位二於テ之レアルヤモ計り難シ特二熊皮二於ケル砄究八單 =2䇠所ノ切片二過ギザルバ此感蔍々深シ

然监シテ以上 14 種ノ動鞄二於ケル汗腺ノ構造, 圖解ノ凡テ

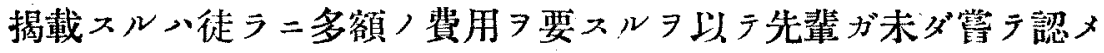
ザリシ汗腺ノ中ョリ代表者トシテ犬ノ囊狀汗腺ト猿ノ絲球狀汗腺 トヨ選定シ附圖トシテ揭グ

但シ汗腺ガ分泌 7 營篇スル所ノ㗢作中ナりヤ將タ又休息中ナリ ヤ組織學上ノ見地ヨリ制别七ントスル研究い多大ノ困難 7 伴七 テ終ニ失敗二歸シ爱二報告スルノ材料トナシ得ザシシコトハ甚ダ 遗憾ナリ

倘和重要ナル問題ハ汗腺ノ構造トソレニ於ケル神絉ノ緊張ト 芼然無關係ナルントナリ例へバ牛、囊狀汻腺ノ動物ナレドモ人及

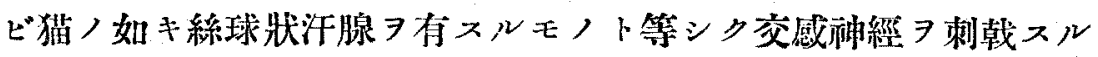
二俄テ發汗シ羊ハ絲球狀汗腺ヨ有スレドモ副艾威种經ノ刺戟二テ ハ人及ビ猫卜粠りテ發汗スルコトナク却テ枩威神經ノ刺戟 7 受ク

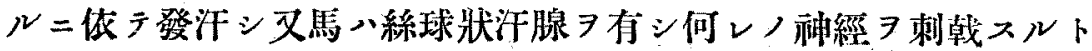


モ發汗ス故二汗腺二於ヶル种經ノ作用二依リテ分類スル時ハ次ノ 如シ

（1）交威神經，發汗動物 羊

(2) 副艾感神經, 發汗動物 人牛猫

(3) 兩種, 神經, 發汗動物 馬

故二汗腺ノ構造下發汗神經, 種類卜 如 $三$

\begin{tabular}{|c|c|c|c|}
\hline $\begin{array}{l}\text { 汗腺八構造 } \\
\text { 發汗种經 }\end{array}$ & 綵 球 狀 & 霟 & 狀 \\
\hline 交 感 紳 經 & 羊 & & \\
\hline 副交感神 經 & 人 猫 & 4 & \\
\hline 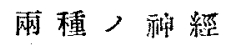 & 馬 & & \\
\hline
\end{tabular}

今ャ余等 其他ノ動物二就テ發汗神經 7 砳究スべキ機會二到蓬 セり即チ假命微量，發汗ニテモ其濕度 計量スべキ裝置

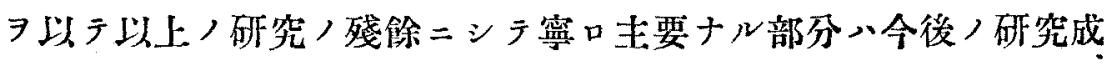
績二待ッ

\section{A HISTOLOGICAL STUDY ON THE SWEAT GLANDS OF MAMMAIS.*}

Dr. Kilchiro Muto.

Director of the Army Veterinary Schoo', Tokyo.

In the year 1916 and 1917 the author published the opinion, that the sweat glands are innervated not only by the sympathic nerve, but also by the parasympathic and the function of those two nerves upon the glands varies with the kinds of animals, for instance, in men, cattle and cats the glands are influenced to secrete by the parasympathic nerve stimulation, while in the sheep by the sympathic, but never by the parasympathic, on the other hand, in the horise as well by the sympathic as by the parasympathic in a remar-

* Received for publication, December 15,1924 . 
kable degree. After this discovery the author has made the following paradoxical experiment:- If a large quantity of the well-known strong anidrotica "atropin" is injected intravenously to a horse, a remarkable excitement with abundant sweating will always be observed. But if, in this case, a certain quantity of chloralhydrate will be given per rectum, so as to calm the animal, then the sweating will be influenced to cease. If is much more curious that, by the intravenous injection of the diaphoretica "pilocarpin", the sweating caused by the injection of atropin, can be stopped immediately, because the pilocarpin subsides the excitement by atropin. In connection with the above mentioned work, the author has studied the histological structure of the sweat glands in various mammals and has found that in man, horse, cat, sheep, wild boar, ape, pig, mouse, white rat and rat they are coiled gland, that in the cattle, dog and goat they are bag-form gland, and that the guinea pig, rabbit and bear have no gland, so far as the author researched.

The attached figures illustrate the coiled gland of ape and the bag-form gland of dog.

(Author's abstract from his Japanese paper.) 
附圖說明 第1 圆 大(背部) ノ汗腺(約50倍攄大) $\mathrm{H}$ 八毛㮛 第2圖同上（約 250 倍摭大）

第3 圖 猿(背部) >汗腺(約 50 倍擴大) $\mathrm{T}$ 八皮脂 $\mathrm{H}$ 八毛根 $\mathrm{S}$ 八汗腺

第4圖同上（娞 200 倍摭大）

\section{EXPLANATION OF PLATES}

Fig. 1. Sweat gland of the dog. $(\times 50)$. H, hair root; S, sweat gland.

Fig. 2. The same. $(\times 250)$.

Fig. 3. Sweat gland of the ape. ( $\times 50)$. T, sebaceous gland; $\mathrm{H}$, hair root;

$\mathrm{S}$, sweat gland.

Fig. 4. The same. $(\times 250)$. 
PLATE I

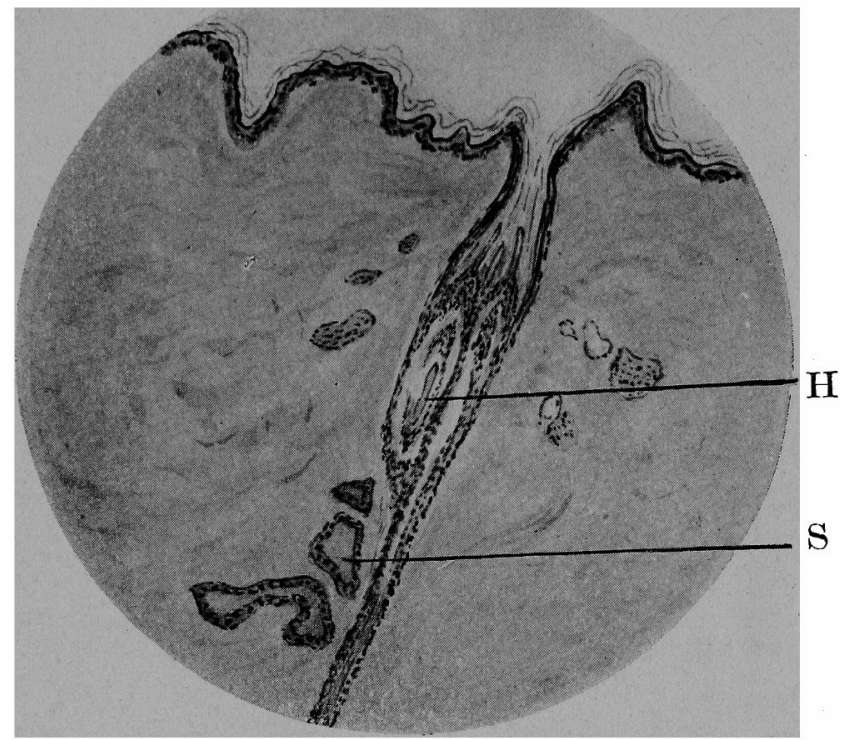

FIG. 1

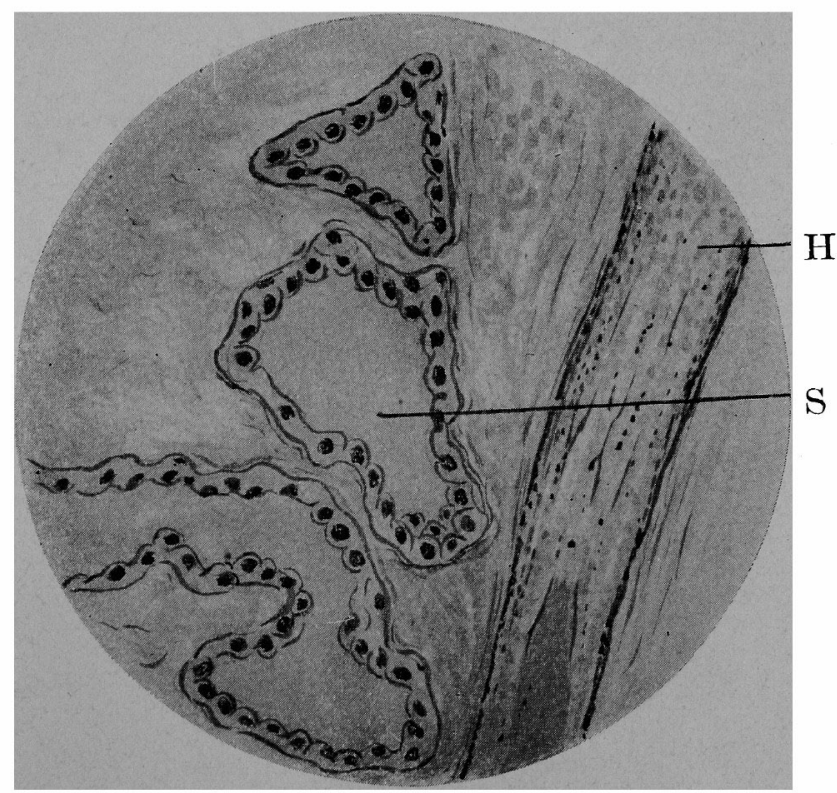

FIG. 2 
PLATL II

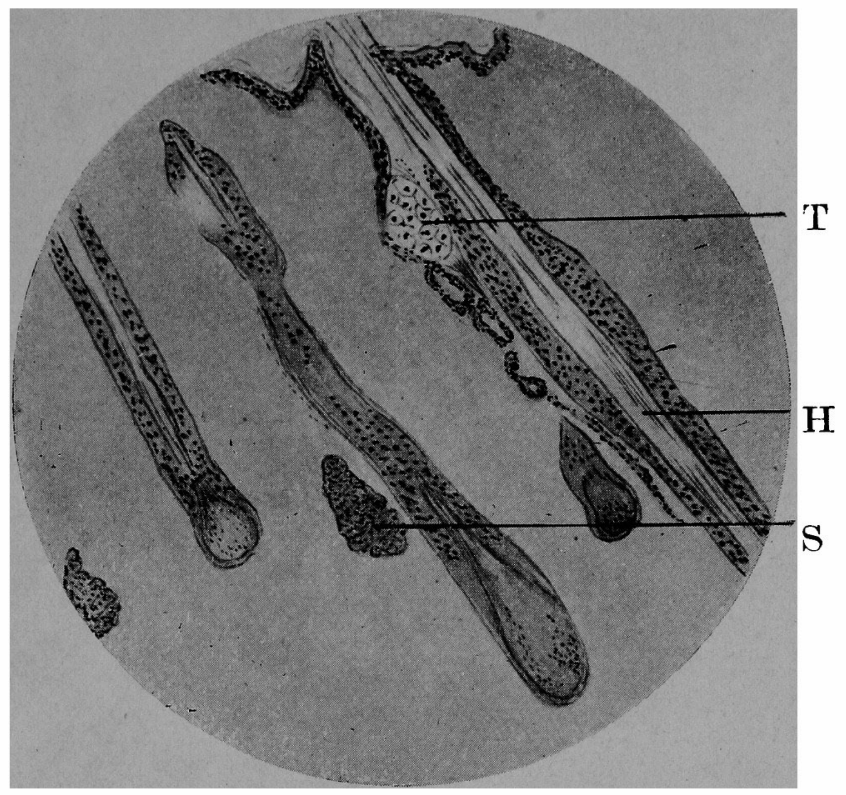

FIG. 3

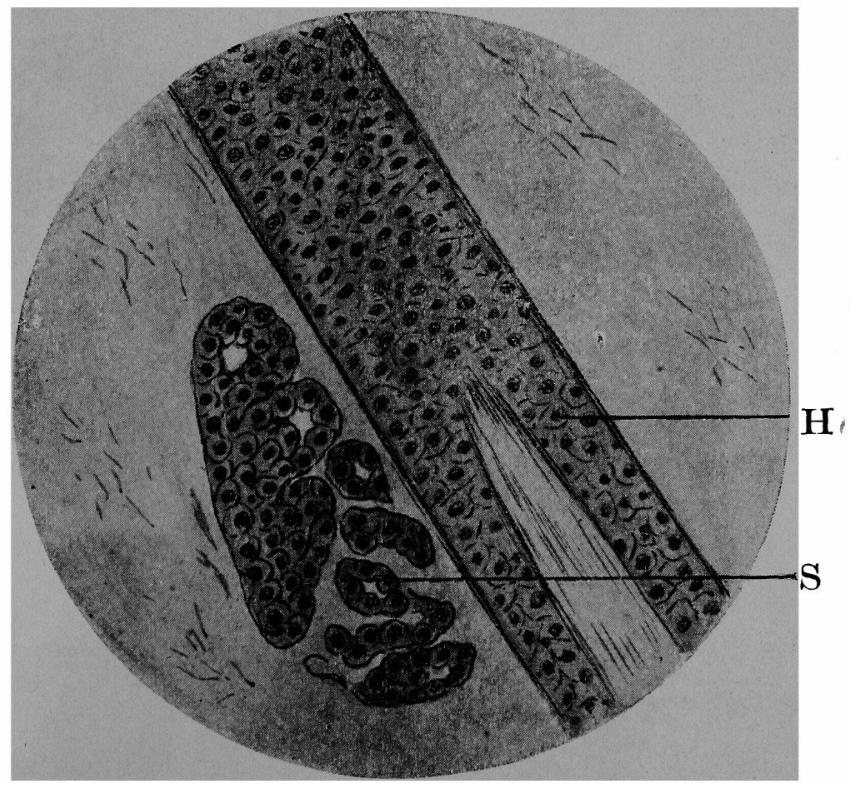

Fig. 4 